\begin{tabular}{|c|c|}
\hline 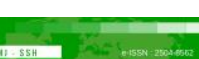 & Malaysian Journal of Social Sciences and Humanities (MJSSH) \\
\hline Malaysian Journal of & Volume 6, Issue 8, August 2021 \\
\hline (MJ - SSH) & e-ISSN : 2504-8562 \\
\hline & $\begin{array}{l}\text { Journal home page: } \\
\text { www.msocialsciences.com }\end{array}$ \\
\hline
\end{tabular}

\title{
Analisis Statistik Kesahan dan Kebolehpercayaan Ujian Pencapaian Reka Bentuk Elektrik
}

\author{
Zaharah Che Isa', Nurulwahida Azid'1 \\ ${ }^{1}$ School of Education, Universiti Utara Malaysia (UUM) \\ Correspondence: Zaharah Che Isa (zahisa@gmail.com)
}

\begin{abstract}
Abstrak
Kajian ini bertujuan membina instrumen ujian pencapaian topik reka bentuk elektrik mata pelajaran Reka Bentuk dan Teknologi tingkatan dua, membuat penilaian dan mengesahkannya serta menjadikannya sah dan boleh dipercayai. Instrumen ini mengandungi 20 item iaitu 10 item aneka pilihan (Bahagian A) dan 10 item subjektif (Bahagian B). Proses kajian melibatkan empat fasa iaitu i) pembinaan instrumen; ii) analisis kesahan pakar; iii) analisis kualitatif berdasarkan cadangan pakar; dan iv) analisis kebolehpercayaan. Proses pembinaan instrumen bersumberkan kepada Dokumen Standard Kurikulum dan Pentaksiran (DSKP), Reka Bentuk dan Teknologi (RBT) tingkatan 2 dan domain kognitif Taksonomi Bloom. Analisis kesahan pakar instrumen melibatkan 10 pakar yang terdiri daripada guru cemerlang RBT, pegawai SISC+ Teknik dan Vokasional, Pegawai Teknik dan Vokasional dan pensyarah bidang kurikulum Teknik dan Vokasional UTHM. Manakala bagi analisis kebolehpercayaan pula, kajian telah dilaksanakan kepada 70 pelajar tingkatan dua yang telah mempunyai pengetahuan kognitif topik reka bentuk elektrik. Hasil kajian mendapati bahawa min keseluruhan instrumen ialah 7.85 dengan nilai minimum 7.10 dan maksimum 8.40. Dapatan analisis kesahan instrumen kebolehpercayaan antara penilai melalui pekali korelasi intrakelas (ICC) pula mendapati, nilai indeks kebolehpercayaan ialah .810 berdasarkan $95 \%$ sela keyakinan antara .584 ke $.944(F(9,171)=5.261, \mathrm{p}<.000)$. Selain itu, data kualitatif melalui ulasan pakar juga menunjukkan bahawa instrumen ujian adalah baik dan mematuhi standard pembinaan ujian pencapaian. Hasil analisis kebolehpercayaan instrumen terhadap 70 pelajar tingkatan dua juga memperoleh nilai kebolehpercayaan cronbach alpha yang memuaskan iaitu .700 untuk bahagian A dan .760 bagi Bahagian B. Justeru, kajian ini membuktikan bahawa, pembinaan instrumen telah dilaksanakan secara sistematik dan mengikut standard yang ditetapkan, memperoleh nilai kesahan dan kebolehpercayaan yang memuaskan serta sah untuk digunakan dalam mana-mana kajian yang melibatkan ujian terhadap pencapaian topik reka bentuk elektrik tingkatan dua.
\end{abstract}

Kata kunci: ujian pencapaian, reka bentuk elektrik, kesahan, kebolehpercayaan, pekali korelasi intrakelas

\section{Statistical Analysis of Validity and Reliability of Electrical Design Achievement Tests}

\begin{abstract}
This study aims to construct an electrical design topic achievement test instrument of Design and Technology form two subjects, make an assessment and validate it as well as make it valid and reliable. This instrument contains 20 items, namely 10 multiple choice items (Part A) and 10 subjective items
\end{abstract}


(Part B). The research process involves four phases namely i) instrument construction; ii) expert validity analysis; iii) qualitative analysis based on expert reviews; and iv) reliability analysis. The instrument construction process based on Curriculum and Assessment Standard Document (DSKP), Design and Technology (RBT) form 2 and the cognitive domain of Bloom's Taxonomy. The instrument expert validity analysis involved 10 experts who were excellent RBT teachers, SISC+ Technical and Vocational officers, Technical and Vocational Officers and Technical and Vocational lecturers in curriculum from UTHM. As for the reliability analysis, the study was conducted on 70 students in form two, who already have cognitive knowledge of electrical design topics. The results of the study found that the overall mean of the instrument was 7.85 with a minimum value of 7.10 and a maximum of 8.40. Findings of instrument validity analysis through inter-rater reliability with intraclass correlation coefficient (ICC), the reliability index value is .810 based on $95 \%$ confidence interval between .584 to $.944(F(9,171)=5,261, p<.000)$. In addition, qualitative data through expert reviews also show that the instruments were good and complies with the construction standards of achievement tests. The results of the instrument reliability analysis of 70 students also obtained a satisfactory cronbach alpha reliability value of .700 for multiple choice items and .760 for subjective items. Thus, this study proves that, the construction of the instrument has been implemented systematically and in accordance with the set standards. The findings of the study on the analysis of validity and reliability also found that the values obtained were satisfactory. Therefore this achievement test is valid and reliable for use in any study involving the achievement test of a form two electrical design topic.

Keywords: achievement test, electrical design, validity, reliability, intraclass correlation coefficients

\section{Pengenalan}

Prestasi sistem Pendidikan di Malaysia telah diiktiraf di peringkat antarabangsa seiring dengan negara maju yang lain. Laporan daripada Forum Ekonomi Dunia (World Economic Forum), antaranya, telah mengiktiraf Malaysia sebagai sebuah negara yang mempunyai tahap persaingan lebih baik dalam bidang pendidikan dari 141 buah negara di seluruh dunia pada tahun 2018. Berdasarkan laporan terbaharunya, Malaysia menduduki tangga ke-19 lebih baik daripada negara maju seperti United Kingdom (UK) di tangga 20, Perancis (26), dan Jepun (31) (Sualman, 2019). Hal ini demikian kerana, sistem pendidikan negara sentiasa melakukan transformasi dalam meningkatkan kualiti pendidikan kebangsaan dan menjadikannya agenda utama dalam membangunkan modal insan serta kemajuan negara dalam bidang yang lain (Kementerian Pendidikan Malaysia, 2019). Justeru, pelbagai dasar yang menyokong, antaranya ialah diperkenalkan beberapa mata pelajaran baharu termasuklah mata pelajaran Reka Bentuk dan Teknologi (RBT) yang berunsurkan STEM (Sains, Teknologi, Kejuruteraan dan Matematik) untuk meningkatkan kualiti pembelajaran. Pendekatan STEM ialah pengajaran dan pembelajaran yang mengaplikasikan pengetahuan, kemahiran dan nilai STEM melalui inkuiri, penyelesaian masalah atau projek dalam konteks kehidupan harian, alam sekitar dan masyarakat tempatan serta global (Kementerian Pendidikan Malaysia, 2016). Menurut Fioriello (2021), pula, mata pelajaran berunsurkan STEM adalah untuk mengubah konsep pembelajaran berpusatkan guru yang tipikal kepada pembelajaran yang didorong oleh penyelesaian masalah, penemuan, pembelajaran eksploratori, dan memerlukan penglibatan pelajar secara aktif dalam situasi untuk mencari penyelesaiannya. Justeru, mata pelajaran RBT dengan kandungan sub topik yang berunsurkan STEM diperkenalkan melalui Pelan Pembangunan Pendidikan Malaysia (PPPM) 2013-2025 kepada pelajar adalah untuk menyediakan pelajar dengan pendekatan STEM seawal usia 13 tahun bagi sekolah menengah (Kementerian Pendidikan Malaysia, 2012).

Reka bentuk elektrik merupakan salah satu sub topik dalam mata pelajaran Reka Bentuk dan Teknologi (RBT) tingkatan dua merupakan topik asas yang penting kepada topik lain selanjutnya di tingkatan dua dan tiga (Kementerian Pendidikan Malaysia, 2016). Walau bagaimanapun, menurut Masingan dan Sharif (2019), reka bentuk elektrik merupakan antara sub topik yang agak sukar untuk dikuasai pelajar. Tambahan pula, ia merupakan silibus baharu yang menyebabkan kebanyakan guru mengalami kesukaran untuk menguasainya dan seterusnya memberi kesan terhadap penyampaian dalam bilik darjah. Hal ini 
disokong oleh Adisel dan Prananosa (2020), yang menyatakan, guru yang mengajar mata pelajaran baharu berhadapan masalah untuk menguasai kurikulum dan kandungan mata pelajaran yang sekaligus boleh menjejaskan proses pengajaran dan pembelajaran.

Proses pengajaran dan pembelajaran bukan sekadar proses penyampaian isi pelajaran oleh guru sematamata sebaliknya ia diiringi dengan kefahaman guru bahawa maklumat pembelajaran yang disampaikannya telah pun diterima dan difahami oleh pelajar. Salah satu daripada cara untuk mendapatkan maklumat ini ialah melalui pelaksanaan ujian pencapaian. Ujian pencapaian merujuk kepada ujian terhadap perkembangan pengetahuan atau kemahiran (Miller, Linn \& Gronlund, 2013). Menurut Julie, Joseph, Janet, April, Christopher dan Molly (2019), kebanyakan ujian pencapaian dilaksanakan untuk mengukur pengetahuan dan kemahiran yang diperoleh dalam sesi pembelajaran yang terancang menggunakan gred tertentu. Gagne (1970), pula mendefinisikan ujian sebagai cara sistematik untuk mengukur tingkah laku seseorang individu kerana beliau menyatakan bahawa pembelajaran dikaitkan dengan perubahan kepada tingkah laku. Justeru adalah penting bahawa kajian terhadap pembangunan item ujian pencapaian reka bentuk elektrik harus dilaksanakan dengan cara yang sistematik, mengikut peraturan tertentu dan berpandukan kepada sumber yang diakui. Oleh yang demikian, pembangunan instrumen ujian pencapaian topik reka bentuk elektrik akan berpandukan kepada Dokumen Standard Kurikulum dan Pentaksiran (DSKP) mata pelajaran Reka Bentuk dan Teknologi (RBT) tingkatan 2 (KPM, 2016); dan juga enam aras yang terdapat dalam Taxonomi Bloom (Anderson \& Krathwothl, 2001).

\section{Sorotan Literatur}

Ujian pencapaian merupakan cara terancang dan sistematik untuk mengukur pencapaian seseorang pelajar (Kementerian Pendidikan Malaysia, 2016). Justeru proses pembinaannya juga memerlukan kaedah yang sistematik melalui pengetahuan khusus bagi membolehkannya sah dan boleh dipercayai sebelum digunakan. Terdapat banyak kajian yang telah dilaksanakan berkaitan pembinaan ujian pencapaian. Namun, kebanyakan pembinaan ujian yang telah dilakukan oleh guru, didapati tidak menepati standard pembinaan ujian seperti mana yang dikehendaki (Osadebe, 2014). Walau bagaimanapun, pembinaan ujian ini akan dapat dilaksanakan dengan baik sekiranya guru diberi pendedahan dan bimbingan tentang kaedah serta prosedur pembinaan ujian yang sewajarnya (Osadebe, 2013).

Pembinaan sesuatu ujian pencapaian perlu mengambil kira beberapa aspek untuk menjadikannya sah dan boleh dipercayai. Selain itu, ia juga perlu dibina berpandukan kepada ciri-ciri ujian yang baik iaitu validity, realibility, practicality, administrability, comprehensiveness objectivity, simplicity dan scorability seperti mana yang disarankan oleh Miller, Linn dan Gronlund (2013). Menurut Osadebe (2014) ujian yang telah melalui proses kesahan dan kebolehpercayaan boleh diberikan kepada pelajar setelah memastikan pelajar telah mengikuti sesi pembelajaran yang berkaitan ujian itu sepenuhnya. Hal ini untuk memastikan bahawa ujian yang baik telah diberikan kepada semua pelajar yang telah mempunyai pengetahuan tentang kandungan ujian yang diberikan. Justeru untuk menjadikan instrumen itu baik, maka proses kesahan dan kebolehpercayaan perlu dilaksanakan.

Kesahan bermaksud instrumen penyelidikan yang digunakan haruslah boleh mengukur dengan tepat apa yang ingin diukur dalam kajian (Creswell \& Creswell 2018; Talib, 2013). Dalam maksud yang sama, kesahan sesuatu ujian adalah untuk menguji ketepatan sesuatu alat ukur yang digunakan dalam kajian. Manakala kebolehpercayaan pula merujuk kepada ketekalan atau kestabilan maklum balas yang diberikan oleh responden merentasi item, soalan atau konstruk (Creswell \& Creswell, 2018)). Ini bermakna seseorang individu itu akan mendapat skor yang sama daripada sesuatu instrumen seandainya kebolehan individu itu adalah tekal atau trait yang hendak diukur itu tidak berubah walaupun diukur berkali-kali dengan instrumen yang sama.

Antara kajian analisis kesahan dan kebolehpercayaan yang telah dilaksanakan oleh pengkaji terdahulu ialah kajian yang dijalankan oleh Kara \& Celikler (2015) terhadap topik Matter Changing. Kajian ini melibatkan pembinaan 48 item soalan berbentuk aneka pilihan berpandukan kepada enam aras 
Taksonomi Bloom. Proses kesahan dilaksanakan oleh empat pakar penilai, manakala 354 pelajar gred enam telah menjadi sampel kajian bagi memperoleh nilai kebolehpercayaan. Melalui analisis nilai pekali kebolehpercayaan Kuder Ricahardson-20 telah memperoleh nilai 0.763. Selain itu, kajian oleh Osadebe (2014) pula telah membuat kajian pembinaan ujian topik ekonomi. 100 soalan aneka pilihan telah dibina berpandukan kepada aras Taksonomi Bloom (Forehand, 2010) iaitu pengetahuan, pemahaman, aplikasi, analisis, sintesis dan penilaian. Hasil analisis memperoleh pekali kebolehpercayaan 0.95 yang ditetapkan menggunakan Kuder-Richardson. Justeru, pembinaan item ujian yang dilakukan secara terancang, sistematik dan menggunakan sumber yang sahih akan memastikan sesuatu ujian tersebut sah dan boleh dipercayai serta boleh digunakan dalam proses mengukur tahap pengetahuan dalam satu-satu proses pembelajaran.

\section{Soalan Kajian}

i.Apakah nilai min bagi setiap item ujian pencapaian?

ii.Apakah nilai pekali korelasi antara kelas (Intraclass correlation coefficient) bagi instrumen ujian pencapaian topik reka bentuk elektrik?

iii.Apakah pandangan pakar terhadap ujian pencapaian topik reka bentuk elektrik?

iv.Apakah nilai kebolehpercayaan instrumen ujian pencapaian topik reka bentuk elektrik?

\section{Metod Kajian}

Kajian ini menggunakan pendekatan kuantitatif dengan pemilihan reka bentuk kajian melalui pembinaan dan pengesahan instrumen ujian pencapaian. Tujuan kajian adalah untuk mendapatkan nilai kesahan dan kebolehpercayaan instrumen. Oleh itu, data diperoleh daripada instrumen soal selidik yang diedarkan kepada 10 orang pakar penilai dan 70 pelajar tingkatan dua dalam daerah Baling Kedah yang mempunyai pengetahuan kognitif reka bentuk elektrik sedia ada. Pelajar tingkatan dua dipilih kerana instrumen ini merupakan instrumen ujian bagi topik reka bentuk elektrik tingkatan dua. Bilangan sampel dalam kajian rintis ini memadai kerana menurut Cooper dan Schindler (2011), bilangan sampel yang sesuai dalam kajian rintis adalah antara 25 hingga 100 orang. Manakala Johanson dan Brooks (2010) pula mencadangkan bilangan minimum adalah seramai 30 orang. Dua jenis instrumen yang digunakan dalam kajian iaitu borang penilaian pakar instrumen yang mempunyai skala skor 1 hingga 10 dan ujian pencapaian topik reka bentuk elektrik yang mengandungi 20 soalan .

\section{Hasil Kajian}

Kajian ini melibatkan empat fasa iaitu; fasa 1 yang merupakan fasa pembinaan item melalui pelbagai sumber. Fasa 2 merupakan fasa penilaian dan kesahan oleh pakar penilai. Manakala fasa 3 ialah fasa analisis kualitatif dan fasa 4 pula merupakan fasa analisis kebolehpercayaan melalui kajian rintis. Rajah 1 memaparkan ringkasan fasa yang terlibat dalam proses kajian yang telah dilaksanakan.

Rajah 1: Fasa dalam Proses Kajian

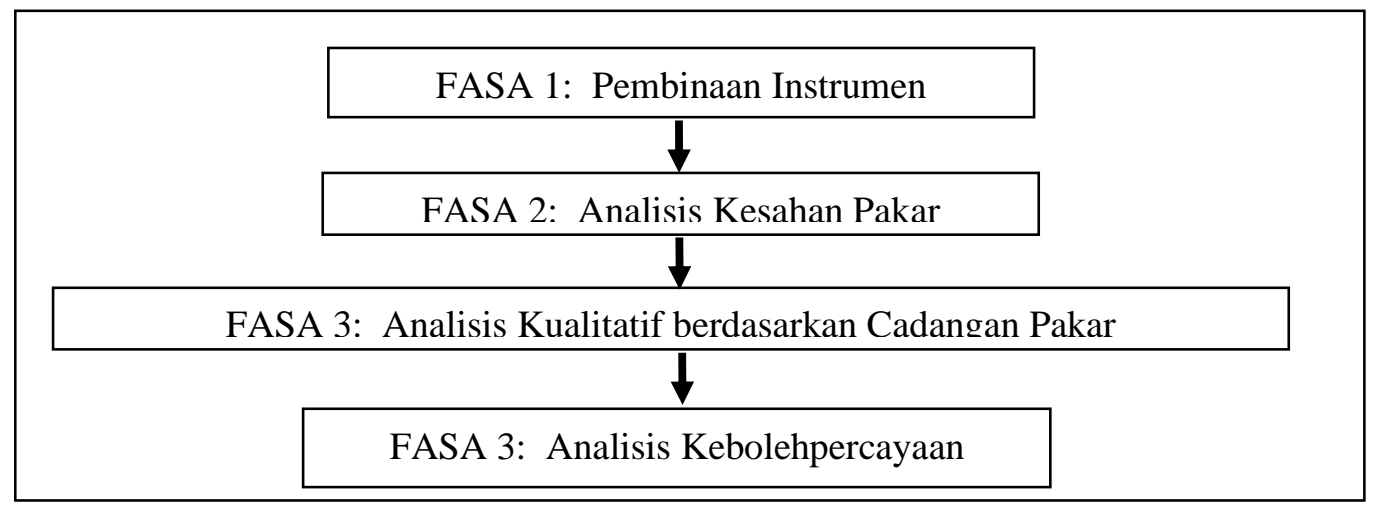




\section{Fasa 1: Pembinaan Instrumen}

Pembinaan instrumen ujian pencapaian topik reka bentuk elektrik melibatkan dua sumber iaitu; i) Dokumen Standard Kurikulum dan Pentaksiran (DSKP) mata pelajaran Reka Bentuk dan Teknologi (RBT) tingkatan 2 (KPM, 2016); dan ii) Domain Kognitif Taxonomi Bloom (Anderson \& Krathwothl, 2001). Kedua-dua sumber ini dijadikan sebagai panduan penyelidik dalam membina dan membangunkan 20 item yang terdiri daripada 10 item objektif dan 10 item subjektif. Selain itu, ciri ujian yang baik (validity, realibility, practicality, administrability, comprehensiveness objectivity, simplicity dan scorability) yang disarankan oleh Miller, Linn \& Gronlund (2013) turut digunakan sebagai panduan dalam membangunkan item ujian ini. Kesemua item yang dibina mencakupi keseluruhan lapan sub topik yang terdapat dalam DSKP mata pelajaran RBT tingkatan dua.

Jadual 1 memaparkan jadual spesifikasi item bagi pembahagian item lapan sub topik dan aras Taksonomi Bloom proses pembinaan item berdasarkan DSKP RBT tingkatan dua. Selain itu pembinaan setiap item adalah merujuk kepada enam aras domain kognitif yang terkandung dalam Taksonomi Bloom (Anderson \& Krathwohl, 2001). Aras pembinaan item adalah bermula daripada aras rendah iaitu aras mengingat (C1) dan aras memahami (C2); aras sederhana iaitu aras mengaplikasikan (C3) dan aras menganalisis (C4); manakala aras tinggi iaitu aras menilai (C5) dan aras mencipta (C6). Terdapat 20 item yang membawa kepada wajaran 100\%. Jadual ini juga memaparkan jumlah item, nombor soalan berdasarkan topik dan wajaran bagi setiap sub topik secara terperinci.

Jadual 1: Pembahagian Item Berdasarkan Sub Topik dan Aras Taksonomi Bloom

\begin{tabular}{|c|c|c|c|c|c|c|c|c|c|}
\hline & \multirow[b]{2}{*}{$\begin{array}{c}\text { Sub Topik Reka Bentuk } \\
\text { Elektrik }\end{array}$} & \multicolumn{6}{|c|}{ Taksonomi Bloom } & \multirow[b]{2}{*}{ 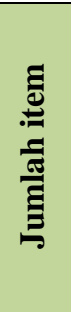 } & \multirow[b]{2}{*}{ 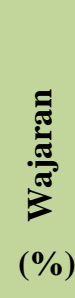 } \\
\hline & & 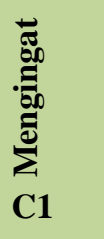 & 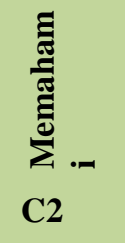 & 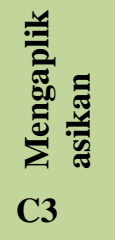 & 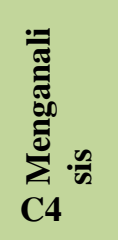 & 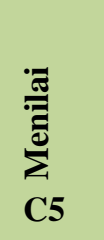 & 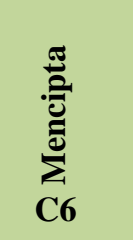 & & \\
\hline 1 & Elemen Sistem Elektrik & $\begin{array}{l}1(\mathrm{~A}), \\
2(\mathrm{~A}),\end{array}$ & $\begin{array}{l}6(\mathrm{~A}) \\
7(\mathrm{~A})\end{array}$ & & & & & 4 & 20 \\
\hline 2 & $\begin{array}{l}\text { Reka Bentuk Litar Peralatan } \\
\text { Elektrik }\end{array}$ & $\begin{array}{l}3(\mathrm{~A}) \\
4(\mathrm{~A})\end{array}$ & $8(\mathrm{~A})$ & & & & & 3 & 15 \\
\hline 3 & Pengiraan Parameter Elektrik & $5(\mathrm{~A})$ & $9(\mathrm{~A})$ & & 13 (B) & & & 3 & 15 \\
\hline 4 & $\begin{array}{l}\text { Lakaran Reka Bentuk Litar } \\
\text { Elektrik }\end{array}$ & & $10(\mathrm{~A})$ & 11(B) & $14(\mathrm{~B})$ & & & 3 & 15 \\
\hline 5 & $\begin{array}{l}\text { Analisis Elemen Sistem } \\
\text { Elektrik pada Gajet }\end{array}$ & & & $12(\mathrm{~B})$ & $15(\mathrm{~B})$ & & & 2 & 10 \\
\hline 6 & $\begin{array}{l}\text { Membina Gajet Elektrik } \\
\text { Berfungsi }\end{array}$ & & & & $16(\mathrm{~B})$ & $18(\mathrm{~B})$ & & 2 & 10 \\
\hline 7 & $\begin{array}{l}\text { Pengujian dan Penilaian } \\
\text { Kefungsian Gajet. }\end{array}$ & & & & 17 (B) & 19 (B) & & 2 & 10 \\
\hline 8 & $\begin{array}{l}\text { Penambahbaikan Reka Bentuk } \\
\text { Gajet }\end{array}$ & & & & & & $20 \mathrm{~B})$ & 1 & 5 \\
\hline & MLAH ITEM & & 10 & & & & 3 & 20 & \\
\hline & IJARAN (\%) & & 50 & & & & 15 & & 100 \\
\hline
\end{tabular}

\section{Fasa 2: Analisis Kesahan Pakar}

Proses penilaian dan pengesahan pakar dilaksanakan setelah proses pembinaan item instrumen selesai dilaksanakan. Penilaian dan pengesahan dilaksanakan melalui semakan pakar bidang kurikulum dan pembinaan ujian pencapaian. Semakan pakar merupakan keperluan bagi memastikan ketepatan konstruk serta kejelasan kandungan (Taherdoost, 2016). Oleh yang demikian, instrumen ujian pencapaian yang 
dibina penyelidik telah diberikan kepada pakar yang mempunyai kemahiran dalam bidang berkaitan untuk disemak bagi memastikan isi kandungannya bersesuaian dan menepati matlamat kajian.

Pemilihan pakar penilai terdiri daripada 10 orang pakar penilai yang merupakan guru RBT, pegawai SISC+ Teknik dan Vokasional Pejabat Pendidikan Daerah (PPD), pegawai Teknik dan Vokasional Jabatan Pendidikan Negeri Kedah (JPN), pegawai di Kementerian Pendidikan Malaysia (KPM) serta pensyarah bidang kurikulum di Universiti Tun Hessein Onn Malaysia (UTHM). Pakar penilai yang dilantik merupakan individu yang berpengalaman dalam bidang kurikulum, pentaksiran dan juga pembinaan item mata pelajaran RBT.

Pakar penilai diminta untuk memberikan rating skor satu (1) hingga sepuluh (10) pada setiap item ujian di bahagian yang disediakan dalam borang pakar penilai. Skor 1 (sangat lemah) hingga 10 (sangat baik) merupakan tahap persetujuan pakar terhadap item yang telah dibina. Ruangan komen dan cadangan juga disediakan sekiranya pakar memberikan rating skor kurang daripada enam bagi tujuan penambahbaikan item oleh penyelidik.

\section{Hasil Analisis Deskriptif}

Jadual 2 memaparkan nilai min setiap item dalam instrumen ujian pencapaian topik reka bentuk elektrik berdasarkan penilaian 10 orang pakar. Secara ringkasnya, analisis statistik item bagi ujian pencapaian topik reka bentuk elektrik ini boleh dilihat pada Jadual 3 dengan nilai minimum min item 7.10 dan maksimum 8.40. Ini bermakna setiap item dan instrumen ini boleh digunakan untuk kajian rintis dan kajian sebenar nanti kerana berdasarkan Creswell dan Creswell (2018), nilai ini dianggap boleh diterima dan sah dijadikan instrumen untuk kajian. Walau bagaimanapun, instrumen akan ditambah baik berdasarkan komen dan cadangan yang telah diberikan oleh panel penilai.

Jadual 2: Analisis Statistik Nilai Min Item Ujian Pencapaian Topik Reka Bentuk Elektrik

\begin{tabular}{lccc}
\hline & Min & Sisihan piawai & N \\
\hline item1 & 7.70 & 1.33749 & 10 \\
item2 & 8.40 & .84327 & 10 \\
item3 & 7.70 & 1.56702 & 10 \\
item4 & 7.70 & 1.41814 & 10 \\
item5 & 8.20 & 1.22927 & 10 \\
item6 & 7.60 & 1.50555 & 10 \\
item7 & 7.40 & 1.71270 & 10 \\
item8 & 7.10 & 1.44914 & 10 \\
item9 & 8.10 & 1.19722 & 10 \\
item10 & 8.40 & 1.34990 & 10 \\
item11 & 8.10 & 1.10050 & 10 \\
item12 & 7.40 & 1.64655 & 10 \\
item13 & 7.80 & 1.22927 & 10 \\
item14 & 7.60 & 1.26491 & 10 \\
item15 & 7.80 & 1.03280 & 10 \\
item16 & 8.40 & .96609 & 10 \\
item17 & 7.50 & 1.84089 & 10 \\
item18 & 8.00 & 1.56347 & 10 \\
item19 & 8.00 & 2.21108 & 10 \\
item20 & 7.60 & 1.50555 & 10 \\
\hline & & &
\end{tabular}


Jadual 3: Analisis Statistik Nilai Minimum dan Maksimum Ujian Pencapaian Topik Reka Bentuk Elektrik

\begin{tabular}{lcccc} 
& Min & Minimum & Maximum & Bilangan item (N) \\
\hline Item & 7.825 & 7.10 & 8.40 & 20 \\
\hline
\end{tabular}

\section{Hasil Analisis Pekali Korelasi Intraclass (ICC)}

Proses pengumpulan skor daripada pakar penilai kemudiannya dianalisis untuk memperoleh nilai kesahan melalui analisis Pekali Korelasi Intraclass (ICC) Two-Way Mixed untuk mendapatkan nilai kebolehpercayaan sepuluh orang pakar penilai atau inter-rater reliability. Dapatan daripada analisis data inter-rater reliability ini digunakan untuk menilai atau mengukur tahap persetujuan antara penilai. Merujuk kepada Jadual 4, didapati bahawa nilai indeks kebolehpercayaan bagi instrumen ujian pencapaian topik reka bentuk elektrik ialah .810 berdasarkan $95 \%$ sela keyakinan antara .584 ke .944 (F $(9,171)=5.261, \mathrm{p}<.000)$. Nilai instrumen ini dianggap tinggi dan sangat memuaskan (Miller, Linn dan Gronlund, 2013). Walau bagaimanapun, proses selanjutnya iaitu pengubahsuaian dan penambahbaikan item tetap perlu dilaksanakan untuk menjadikan item lebih baik dan bersesuaian dengan sampel kajian.

Jadual 4: Analisis Kesahan Instrumen melalui Intraclass Correlation Coefficient (ICC) Ujian Pencapaian Topik Reka Bentuk Elektrik

\begin{tabular}{lccccccc}
\hline & $\begin{array}{c}\text { Intraclass } \\
\text { Correlation }\end{array}$ & \multicolumn{2}{c}{$\mathbf{9 5 \%}$ Confidence Interval } & \multicolumn{3}{c}{ F Test with True Value 0 } \\
\cline { 3 - 8 } & $\begin{array}{c}\text { Lower } \\
\text { Bound }\end{array}$ & $\begin{array}{c}\text { Upper } \\
\text { Bound }\end{array}$ & Value & df1 & df2 & Sig \\
\hline $\begin{array}{l}\text { Single } \\
\text { Measures }\end{array}$ & $.176^{\mathrm{a}}$ & .066 & .456 & 5.261 & 9 & 171 & .000 \\
$\begin{array}{l}\text { Average } \\
\text { Measures }\end{array}$ & $.810^{\mathrm{c}}$ & .584 & .944 & 5.261 & 9 & 171 & .000 \\
\hline
\end{tabular}

Two-way mixed effects model where people effects are random and measures effects are fixed.

a. The estimator is the same, whether the interaction effect is present or not.

b. Type $C$ intraclass correlation coefficients using a consistency definition-the between-measure variance is excluded from the denominator variance.

c. This estimate is computed assuming the interaction effect is absent, because it is not estimable otherwise.

\section{Fasa 3: Analisis Kualitatif berdasarkan Cadangan Pakar}

Pengubahsuaian dan penambahbaikan item instrumen dilakukan berdasarkan kepada komen, cadangan dan ulasan oleh 10 orang pakar penilai terhadap setiap item ujian pencapaian. Komen dan cadangan pakar sangat penting untuk digunakan dalam proses pengubahsuaian dan penambahbaikan item agar menjadi instrumen yang baik bagi tujuan pengujian kepada sampel kajian. Walau bagaimanapun pengubahsuaian keseluruhan item hanya dilakukan sekiranya didapati dua atau lebih penilai yang memberi komen negatif. Hal ini kerana jika hanya seorang pakar yang tidak bersetuju, maka, penyelidik menganggap bahawa item yang dibina adalah tepat atau hampir tepat dengan konstruk yang disediakan.

Secara keseluruhannya terdapat beberapa pengubahsuaian terhadap item yang telah dibuat oleh penyelidik, iaitu i) pengubahsuaian penggunaan istilah; ii) pengubahsuaian struktur ayat; iii) pengubahsuaian melalui penambahan item visual yang lebih sesuai; iv) pengubahsuaian pilihan jawapan; v) keseragaman penyusunan pilihan jawapan; dan vi) pengubahsuaian stem berdasarkan gabungan komen dan cadangan yang pelbagai daripada pakar penilai. Pengubahsuaian ini selari dengan tiga komponen pembinaan item ujian yang dicadangkan oleh Miller, Linn dan Gronlund (2013), iaitu rangsangan (stimulus), pokok soalan (stem), visual dan pilihan jawapan. 
Pengubahsuaian yang melibatkan perubahan istilah adalah seperti pada item 2 dan item 3. Contoh pengubahsuaian melibatkan istilah pada item 2 ialah perubahan daripada "Nyatakan'kepada "Apakah". Selain itu, penyelidik juga membuat pengubahsuaian dari segi susunan dan keseragaman pilihan jawapan. Sebagai contoh pada item 1, penyelidik mengubah kedudukan pilihan jawapan agar lebih teratur dan tersusun. Terdapat juga penambahan visual seperti pada item 4 dan penambahan stimulus item pada item 10 selepas pengubahsuaian dan penambahbaikan. Pengubahsuaian ini dilakukan berdasarkan komen pakar yang menyatakan bahawa, item akan lebih baik dan berkesan sekiranya visual dan stimulus disertakan. Terdapat satu item yang tidak perlu kepada sebarang perubahan kerana dipersetujui sepenuhnya tanpa sebarang komen dan cadangan oleh pakar iaitu item 19. Jadual 5 memaparkan sebahagian item asal yang telah melalui proses pengubahsuaian dan penambahbaikan berdasarkan komen dan cadangan pakar.

Jadual 5: Ringkasan Penambahbaikan Item Ujian Topik Reka Bentuk Elektrik

\begin{tabular}{|c|c|}
\hline No.Item & Item Ujian \\
\hline 1 & $\begin{array}{l}\text { Manakah antara berikut merupakan elemen } \\
\text { elektrik yang betul. } \\
\text { A. Punca } \\
\text { B. (betul tapi tak berkaitan) } \\
\text { Butomatik } \\
\text { C. Sulah dan tak berkaitan) } \\
\text { (betul) } \\
\text { D. Diperbaharui } \\
\text { (salah tapi berkaitan) }\end{array}$ \\
\hline 2 & $\begin{array}{l}\text { Nyatakan fungsi kawalan dalam sistem } \\
\text { elektrik. } \\
\text { A. } \begin{array}{l}\text { Menghasilkan kesan } \\
\text { (salah tapi berkaitan) }\end{array} \\
\text { B. Mengalirkan arus elektrik } \\
\text { (betul tapi tak berkaitan) } \\
\text { C. Membekalkan tenaga elektrik } \\
\text { (salah dan tak berkaitan) } \\
\text { D. Memutus atau menyambung litar } \\
\text { (betul) }\end{array}$ \\
\hline 4 & $\begin{array}{l}\text { Manakah antara berikut, jenis } \\
\text { penyambungan litar elektrik yang betul? } \\
\text { A. Litar bersambung } \\
\text { (betul tapi tak berkaitan) } \\
\text { B. Litar tertutup } \\
\text { (betul) } \\
\text { C. Litar terputus } \\
\text { (salah tapi berkaitan) } \\
\text { D. Litar bocor } \\
\text { (salah dan tak berkaitan) }\end{array}$ \\
\hline
\end{tabular}

Pengubahsuaian dan Penambahbaikan Item

Manakah antara berikut merupakan salah satu elemen elektrik?
A. Punca
B. Sumber
C. Automatik
D. Diperbaharui

(Keseragaman penyusunan pilihan jawapan dan Pengubahsuaian struktur ayat)

Apakah fungsi kawalan dalam sistem elektrik?

A. Mengalirkan arus elektrik

B. Membekalkan tenaga elektrik

C. Menghasilkan kesan kepada beban

D. Memutus dan menyambungkan litar

(Perubahan istilah)

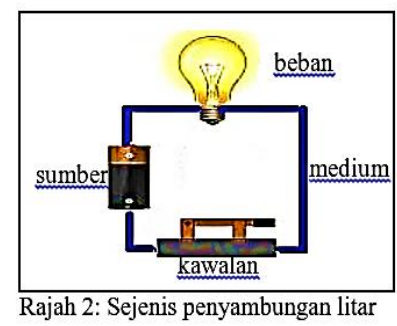

1. Manakah jenis penyambungan litar elektrik yang ditunjukkan pada rajah 2?
A. Litar arus bocor
B. Litar tertutup
C. Litar terbuka
D. Litar pintas

(penambahan visual) 


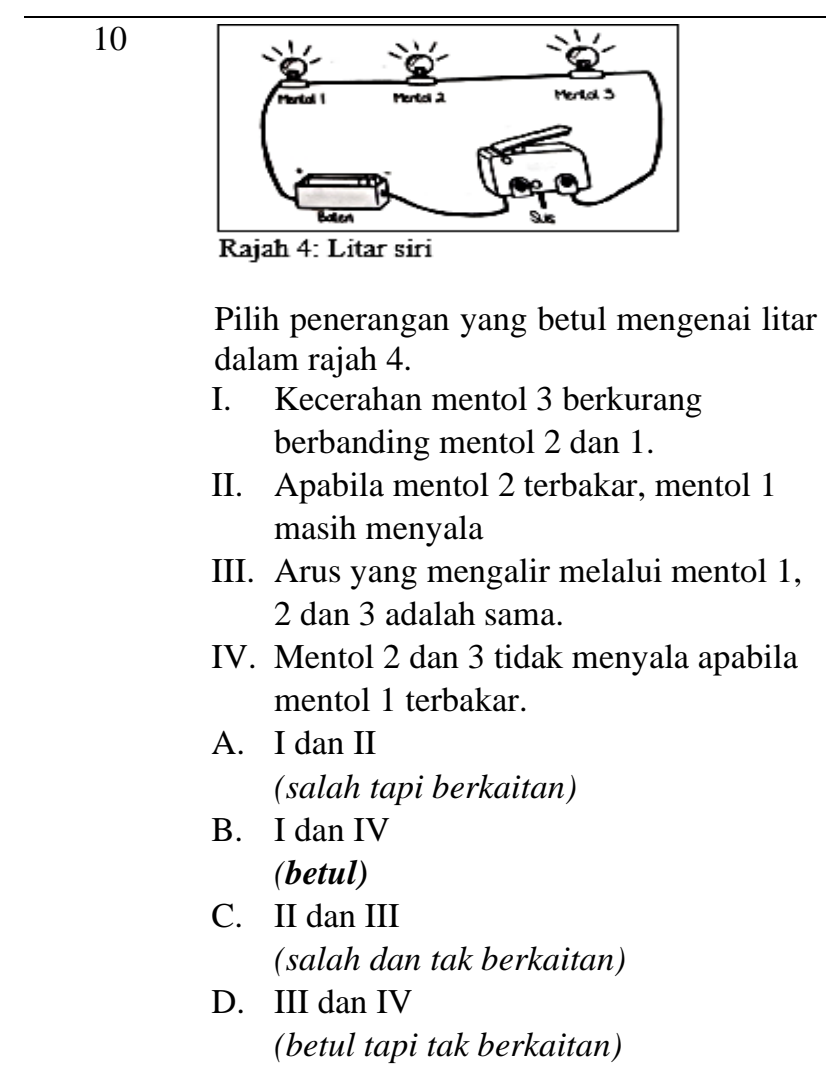

Rajah 5 menunjukkan satu litar siri yang lengkap dan berfungsi.

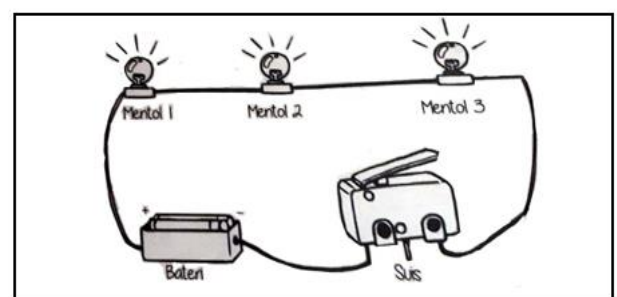

Rajah 5: Litar siri

Berdasarkan rajah 5, pilih penyataan yang betul mengenai litar.

I. Kecerahan mentol 3 berkurang berbanding mentol 1 dan 2

II. Apabila mentol 2 terbakar, mentol 1 masih menyala

III. Arus yang mengalir melalui mentol 1, 2 dan 3 adalah sama

IV. Mentol 2 dan 3 tidak menyala apabila mentol 1 terbakar
A. I dan II
B. I dan IV
C. II dan III
D. III dan IV

(penambahan stimulus item)
19 Rajah 8 menunjukkan dua buah litar elektrik yang berbeza untuk menghasilkan sebuah gajet berfungsi.

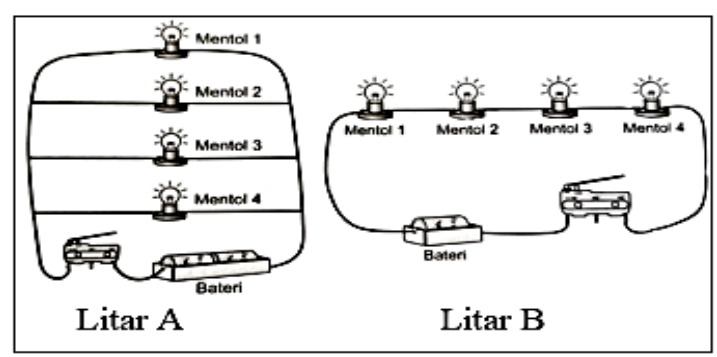

Rajah 8: Dua jenis litar elektrik

Berdasarkan Rajah 8;

19. Nyatakan tiga perbezaan yang terdapat pada kedua-dua litar.

\begin{tabular}{|c|c|}
\hline Litar A & Litar B \\
\hline & \\
\hline & \\
\hline & \\
\hline
\end{tabular}

Tiada perubahan

\section{Fasa 4: Analisis Kebolehpercayaan}

Kebolehpercayaan merujuk kepada ketekalan atau kestabilan maklum balas yang diberikan oleh responden merentasi item, soalan atau konstruk (Creswell \& Creswell, 2018). Ini bermakna seseorang individu akan mendapat skor yang sama daripada sesuatu instrumen seandainya kebolehan individu itu adalah tekal atau trait yang hendak diukur itu tidak berubah walaupun diukur berkali-kali dengan 
instrumen yang sama. Oleh yang demikian, penyelidik menggunakan kaedah ketekalan dalaman bagi menentukan pekali kebolepercayaan iaitu mencari pekali alfa atau dikenali sebagai Cronbach Alpha melalui perisian Statistical Package for Social Science (SPSS).

Kajian analisis kebolehpercayaan dalam kajian ini telah dilaksanakan kepada 70 pelajar tingkatan dua di sebuah sekolah dalam daerah Baling Kedah yang mempunyai pengetahuan kognitif reka bentuk elektrik sedia ada. Bilangan sampel dalam kajian ini memadai kerana menurut Cooper dan Schindler (2011), bilangan sampel yang sesuai dalam kajian rintis adalah antara 25 hingga 100 orang. Manakala Johanson dan Brooks (2010) pula mencadangkan bilangan minimum adalah seramai 30 orang.

Ujian pencapaian mengandungi dua bahagian iaitu bahagian A merupakan item objektif pilihan jawapan A, B, C dan D, manakala bahagian B merupakan item subjektif. Melalui analisis data, nilai kebolehpercayaan yang diperoleh untuk bahagian A ialah .700 dan bahagian B pula memperoleh nilai kebolehpercayaan .760. Ini bermaksud instrumen pencapaian topik ini adalah boleh dipercayai dan sah digunakan dalam kajian sebenar berdasarkan nilai kebolehpercayaan instrumen oleh kepada Miller, Linn dan Gronlund (2013); Guilford dan Fruchter (1956), menyatakan indeks kebolehpercayaan dalam sesuatu ujian adalah memuaskan jika bernilai 0.7 dan ke atas. Jadual 5 memaparkan ringkasan nilai kebolehpercayaan ujian pencapaian topik reka bentuk elektrik.

Jadual 5: Ringkasan Analisis Nilai Kebolehpercayaan Instrumen

\begin{tabular}{lcc}
\hline Instrumen dan Konstruk & $\begin{array}{c}\text { Bilangan Item } \\
\text { (N) }\end{array}$ & $\begin{array}{c}\text { Nilai Cronbach } \\
\text { Alpha }\end{array}$ \\
\hline Ujian Pencapaian Topik Reka Bentuk Elektrik & & \\
1. Bahagian A: Item Objektif Aneka Pilihan (MCQ) & 10 & .700 \\
2. Bahagian B: Item Subjektif & 10 & .760 \\
\hline
\end{tabular}

\section{Perbincangan Kajian}

Kajian ini telah berjaya membangunkan satu instrumen ujian pencapaian topik reka bentuk elektrik yang boleh digunakan oleh guru bagi mengenal pasti tahap pemahaman pelajar setelah melalui proses pengajaran dan pembelajaran topik reka bentuk elektrik. Ujian pencapaian ini telah dibina secara sistematik berpandukan hasil pembelajaran topik reka bentuk elektrik dan enam aras dalam domain kognitif taksonomi Bloom. Justeru, ia merupakan instrumen ujian pencapaian yang standard serta berkualiti. Selain itu, ujian pencapaian ini juga telah memenuhi beberapa kriteria atau ciri-ciri ujian iaitu kesahan, kebolehpercayaan dan keobjektifan. Melalui hasil kajian yang telah memperoleh nilai min setiap item melebihi 0.70 , menjadikan kesemua item adalah baik dan sesuai untuk digunakan dalam kajian berdasarkan kepada Miller et al. (2013). Selain itu nilai kesahan berdasarkan penilaian pakar oleh 10 pakar dan nilai kebolehpercayaan melalui kajian rintis kepada 70 pelajar juga memperoleh nilai tinggi. Oleh yang demikian, ini menjadikan instrumen ujian pencapaian topik reka bentuk elektrik yang dibina penyelidik ini adalah instrumen ujian yang sah dan boleh dipercayai serta sesuai digunakan dalam kajian terhadap pencapaian ujian reka bentuk elektrik yang sebenar nanti.

\section{Kesimpulan}

Pentaksiran melalui ujian pencapaian merupakan salah satu elemen penting dalam pengajaran dan pembelajaran bagi mengukur tahap kefahaman isi pengajaran yang disampaikan kepada kumpulan pelajar. Justeru, kajian yang dilaksanakan ini telah membuktikan bahawa instrumen ujian yang dibina telah mengambil kira faktor dan kriteria pembinaan ujian yang baik dan terancang secara sistematik. Di samping itu, ujian kesahan dan kebolehpercayaan juga dilaksanakan bagi menjadikan instrumen ujian pencapaian tersebut sah dan sesuai untuk digunakan oleh pelajar. Oleh yang demikian, instrumen ini boleh digunakan oleh semua guru dan pelajar dalam menilai tahap kefahaman pelajar terhadap isi pengajaran topik reka bentuk elektrik mata pelajaran Reka Bentuk dan Teknologi tingkatan dua. Hal ini sekaligus dapat membantu guru dan pihak sekolah dalam merancang program intervensi. Selain itu juga, 
pelaksanaan mata pelajaran Reka Bentuk dan Teknologi akan menjadi lebih berkesan kerana murid dapat mengetahui tahap pencapaian diri sendiri dari aspek kognitif. Kajian ini juga boleh dijadikan sebagai panduan kepada guru untuk menghasilkan ujian pencapaian yang berkualiti mengikut kriteria pembinaan yang betul.

\section{Rujukan}

Adisel, A., \& Prananosa, A. (2020). Penggunaan Teknologi Informasi dan Komunikasi dalam Sistem Manajemen Pembelajaran pada Masa Pandemi Covid 19. Journal of Administration and Educational Management, 3(1), 1-10.

Anderson, L.W, \& Krathwohl, D.R. (2001). A Taxonomy for Learning, Teaching, and Assessing: A Revision of Bloom's Taxonomy of Educational Objectives. New York: Longman.

Cooper, D. R., \& Schindler, P. S. (2011). Business research methods (11th ed.). New York: McGrawHill.

Creswell, J. W. \& Creswell, J. D. (2018). Research design: Qualitative, quantitative, and mixedmethod approaches $\left(5^{\text {th }}\right.$ ed.). Thousand Oaks, CA: Sage Publications Ltd.

Fioriello, P. (2021). Understanding the basic of STEM education: What is STEM education? Retrieved from https://drpfconsults.com/understanding-the-basics-of-stem-education/.

Forehand, M. (2010). Bloom's taxonomy. Emerging perspectives on learning, teaching, and technology, 41(4), 47-56.

Gagne, R. M. (1970). The conditions of learning (2nd ed.). Holt, Rinehart \& Winston.

Guilford, J. P. dan Fruchter, B. (1956). Fundamental Statistic in Psychology and Education (5th Edition). Tokyo: Mc Graw Hill.

Johanson, G.A., \& Brooks, G.P. (2010). Initial scale development: sample size for pilot studies. Educational and Psychological Measurement, 70(3), 394-400.

Julie, G. N, Joseph, A. T., Janet, C., April L. G., Christopher, D. W., \& Molly, A. M. S. (2019). Teacher pedagogical content knowledge, practice, and student achievement. International Journal of Science Education, 41(7), 944-963.

Kara, F. \& Celikler, D. (2015). Development of Achievement Test: Validity and Reliability Study for Achievement Test on Matter Changing. Journal of Education and Practice, 6(24), 21-27.

Kementerian Pendidikan Malaysia. (2012). Pelan Pembangunan Pendidikan Malaysia 2013-2025. Kuala Lumpur.

Kementerian Pendidikan Malaysia (2016). Dokumen Standard Kurikulum dan Pentaksiran Reka Bentuk dan Teknologi Tingkatan Dua. Kuala Lumpur: Bahagian Pembangunan Kurikulum.

Kementerian Pendidikan Malaysia (2019). Buku Panduan Pengurusan Mata Pelajaran Reka Bentuk Dan Teknologi (RBT). Putrajaya: Jemaah Nazir.

Masingan, C., \& Sharif, S. (2019). Pengetahuan pedagogi kandungan (PPK) guru bukan pengkhususan Reka Bentuk dan Teknologi (RBT) di Sekolah Menengah Malaysian. Journal of Social Sciences and Humanities, 4(6), 64-71.

Miller, M. D., Linn, R. L., \& Gronlund, N. E. (2013). Measurement and assessment in teaching $\left(11^{\text {th }}\right.$ ed.). New Jersey: Pearson Education Inc.

Osadebe, P. U. (2014). Construction of Economics Achievement Test for Assessment of Students. World Journal of Education, 4(2), 58-64.

Osadebe, P. U. (2013). Evaluation Techniques, DELSU. Journal of Educational Research and Development, 12(1), 56-63.

Sualman, I. (2019, Januari 27). Kualiti pendidikan Malaysia antara terbaik di dunia. Sinar Harian. Dicapai daripada https://www.sinarharian.com.my/article/9910/KOLUMNIS/PendidikanMalaysia

Taherdoost, H. (2016). Sampling methods in research methodology: How to choose a sampling technique for research. International Journal of Academic Research in Management (IJARM), $5(2), 18-27$.

Talib, O. (2013). Asas Penyelidikan tesis penyelidikan dan statistik. Serdang, Selangor: Universiti Putra Malaysia Press. 